\title{
Article \\ Fake News Explosion in Portugal and Brazil the Pandemic and Journalists' Testimonies on Disinformation
}

\author{
João Canavilhas ${ }^{1, *(\mathbb{D})}$ and Thaïs de Mendonça Jorge $\mathrm{e}^{2, *(1)}$ \\ 1 Department of Communication, Philosophy and Politics, Universidade da Beira Interior, \\ 6200-001 Covilhã, Portugal \\ 2 Department of Communication, University of Brasília, Brasília 70864-040, Brazil \\ * Correspondence: jc@ubi.pt (J.C.); thaisdemendonca@gmail.com (T.d.M.J.)
}

Citation: Canavilhas, João, and Thaïs de Mendonça Jorge. 2022. Fake News Explosion in Portugal and Brazil the Pandemic and Journalists' Testimonies on Disinformation. Journalism and Media 3: 52-65. https://doi.org/10.3390/ journalmedia3010005

Academic Editors: Simón Peña-Fernández

Ainara Larrondo-Ureta and

Koldobika Meso-Ayerdi

Received: 31 October 2021

Accepted: 28 December 2021

Published: 6 January 2022

Publisher's Note: MDPI stays neutral with regard to jurisdictional claims in published maps and institutional affiliations.

Copyright: (c) 2022 by the authors. Licensee MDPI, Basel, Switzerland. This article is an open access article distributed under the terms and conditions of the Creative Commons Attribution (CC BY) license (https:// creativecommons.org/licenses/by/ $4.0 /)$.

\begin{abstract}
Orchestrated manipulations spread lies and can create an environment of uncertainty in society, leading to concerns from politicians, scholars, educators, and journalists, among others. In this paper we explore what the emergence of fake news (understood as false news) represents for journalists, trying to answer the following question: Does false news pose a threat to the credibility of good journalism, causing a disruption of the traditional work? To answer it, we interviewed a sample of journalists from various media organizations in Portugal and Brazil. Among the main findings, journalists are aware that fake news is a problem to be faced, as the blame for the dissemination of false news erroneously lies with the profession. They are conscious that something must be done and agree that the best way to fight against fake news is to invest in media literacy. Most of the journalists of our sample think they must be also more cautious to check sources for veracity and for political motivations. The results show that there is a resolve to reinforce the role of journalism in society.
\end{abstract}

Keywords: journalism; fake news; disinformation; misinformation

\section{Introduction}

When the media becomes part of the "texture of experience" (Silverstone 2014, p. 14) and the centrality of the media is felt in people's daily lives, news plays an important role, and it is not by chance that one of today's great phenomena is so-called "fake news".

Foucault (1988, p. 9) would say that what is occurring now is "a discursive explosion", which also happened within the discursive construction of madness or sexuality, for example, decades ago. The discourse, in this case, is produced through the various utterances and silences on a subject in vogue, whose meanings become distorted, "fermented", or simply decontextualized.

In a study involving eight focus groups and a survey in four countries to analyze audience perspectives on fake news, Nielsen and Graves $(2017$, p. 1) found out that some people are not capable of making a clear distinction between news and fake news, and they consider that the expression "fake news" has become a way for politicians to discredit the media that criticize them.

In this paper ${ }^{1}$ we try to find what the recent explosion of fake news represents for journalists. As stated by Kovach and Rosenstiel (2004), journalists write news, and their social contract is with the truth. Our working hypothesis is as follows: Does that mean that false news poses a threat to the credibility of good journalism, causing a disruption of traditional work?

Wolton $(2005,2010)$ advocates that, given the overabundance of information, journalists' main role in the future should be to legitimize the news. Before that, in the beginning of the 20th century, Lévy (2002) predicted that journalists would no longer be needed. Freedom of expression in cyberspace would lead institutions, companies, and individuals to become their own media. It seems that we find ourselves in the antechamber of major changes in journalism and fake news has a role in it. 
Most of the research addressing news focuses on its effects on the audience (Allcott and Gentzkow 2017), but it is important to examine the problem of fake, false, or distorted news on a larger scale within the overall media ecosystem (Canavilhas 2010; Guo and Vargo 2018). It is also critical for academics and journalists to understand how fake news influences real news, and what this has to do with the status quo of journalism and journalists as well (Guo and Vargo 2018, pp. 1-23).

This paper is part of an ongoing project that analyses the impact of fake news in the world of journalists in Portugal and Brazil. The first part of the study was carried out in Brazil (2018) and consisted of the application of a survey among journalists from several media. Part 2 was developed as post-doctorate research at the University of Beira Interior (Portugal 2019-2020). As the research itself was interrupted by the COVID-19 crisis, we present the results of the interviews already conducted in this paper. We interviewed 10 journalists from radio, TV, newspaper, Internet, and magazine outlets. Due to the current situation, most of these interviews were not in-depth, in-person ones. Questions were thus sent by e-mail and via WhatsApp, and the respondents used the available means to answer them, which resulted in an extensive panel of feelings, impressions, and reflections on the panorama of journalism nowadays.

\section{Ground Concepts}

For Egelhofer and Lecheler (2019), "'fake news' is more than just an isolated event or a buzzword to be easily dismissed; it is the expression of a larger and fundamental shift within the technological and political underpinnings of mediated communication in modern democracies". Eco (1984, p. 234) reinforced the idea when he said that we live in an era of digitalization, in a "guerrilla of falsification", where it is difficult to distinguish what is real or unreal. Moreover, it is a threat to society and can destabilize democracy (Allcott and Gentzkow 2017).

On the one hand, we want to know what fake news is. It can be false information disseminated by social media, "a technological dystopia in times of reference crisis and postmodern relativism" (Silva 2019), a piece of news that one does not trust, but it can also be identified with poor journalism, propaganda, advertising in general, and lies (Nielsen and Graves 2017).

On the other hand, we understand fake news in a frame of post-truth, a neologism created to name the social phenomenon developed on the Internet where false content is considered truth due to its massive diffusion. The term "post-truth" was voted Word of the Year in 2016 by The Oxford English Dictionary. According to the concept of post-truth, it is more important to believe that something is true (even if not) than what is true. Thus, the use of the prefix "post" refers to the idea that the concept of truth does not have the same meaning as in the past, and the burst of fake news is part of the larger concept of post-truth.

As Nielsen and Graves (2017) stated, this discussion "plays out against a backdrop of low trust in news media, politicians, and platforms alike-a generalized skepticism toward most of the actors that dominate the contemporary information environment". Misinformation, from the public's point of view, represents only a part of a broader discontent with the information scenery and the deep ditch of transparency and lack of respect for the audience's intelligence that the media and political systems have been digging over the decades.

The former President of the United States, Mr. Donald Trump, claimed that he invented the word "fake" and the term "fake news", which he has used several times in interviews, speeches, and on Twitter: "the Fake News Media hates..."; "Wow, so many Fake News stories today. No matter what I do or say, they will not write or speak the truth. The Fake News Media is out of control!", which he published on social media. But The MerriamWebster Dictionary (2017) remarked that the phrase "fake news" dates at least back to the 19th century. However, it did not deserve its own entry in Merriam-Webster's list of vocables, as it is considered a compound name. The dictionary's lexicographers think the 
meaning is "self-explanatory: fake news is news that is untrue". The term does not need an entry, just as "red car" or "hot day" do not, for example (Steinmetz 2017).

However, other dictionaries have decided to provide an item with definitions. On Dictionary.com, for example, fake news is defined as "false news stories, often of a sensational nature, created to be widely shared online for the purpose of generating ad revenue via web traffic or discrediting a public figure, political movement, company, etc". To the Cambridge English Dictionary it is "false stories that appear to be news, spread on the Internet or using other media, usually created to influence political views or as a joke" (Schaub 2017). Summing up, we can highlight some characteristics in these definitions: Fake news is untrue stories resembling news, which are distributed on the Internet for political, economic, or entertainment purposes or used to cast suspicion on people, companies, or products.

Despite being a new term, Gelfert (2018, pp. 84-117) observed that the expression "fake news" has evolved rapidly. The author reserves the term for cases of "deliberate presentation of (typically) false or misleading claims as news, where these are misleading by design". In this case, he attributes greater importance to the design or the way in which fake news is propagated, thus manipulating the audience.

Tandoc et al. (2017) researched the "newness of fake news" by applying content analysis to 886 fake news articles and trying to point out in which points fake news imitates the characteristics of traditional journalism. They recognized that the long-standing role of journalists in our society as gatekeepers gives them an authority that can be contrasted with the avalanche of fake news. Journalists abide by a code of conduct, ethical precepts, and routines that guarantee them knowledge of what is true and false (Carlson 2017). "'Fake news' producers would imitate the conventions of 'real news' to leech off of journalism's authority and convince readers", the authors say.

Gray et al. (2017) consider "the social disturbance precipitated by 'fake news'" as a kind of uncanny infrastructure and mentioned the problem as a scandal. The aim of their study was to observe the production, distribution, and monetization of complicated versions of false material disseminated throughout certain countries.

\section{Other Terms}

Political actors-like Brazil's president, Mr. Jair Bolsonaro, or the Australian senator Mr. Malcolm Roberts (The Conversation 2019)—and celebrities (Cristiano Ronaldo, when sued for rape) have employed the term "fake news" to discredit information that goes against their own figure or agenda, attesting that the U.S. example had an ominous contagious effect. Together with strong adjectives, the mere word "news" - meaning here the product of journalism - can change its meaning: false, spurious, inaccurate, pollute, crooked. All this debate has given rise to other expressions:

- Misinformation-information disseminated without a harmful intent;

- Dis-information-false information created and shared with the intention to harm, injure or hurt people;

- Mal-information - the sharing of real (or unreal) information to damage (Wardle and Derakshan, Council of Europe. In their report for the Council of Europe, Wardle and Derakshan (2017) examine what they call "information disorder" and other problems, such as filter bubbles and echo chambers, and argue that we are witnessing "information pollution at a global scale". In this technological world of communication facilities, "polluted" messages are being created and amplified by social media at speeds never imagined from malicious accounts (Wardle and Derakshan 2017, p. 4).

The "inflationary use" of the term (Quandt et al. 2019, p. 1) is related to the mediatization process that it has suffered, becoming not only a phrase or an element in someone's discourse, but also an event itself, a mediatic construction, even more so when it is used as an arm to attack others' reputation. Fake news seems to become part of the spectrum of a phenomenon that goes from "unintentional misinformation" to "intentional disinformation" (Quandt et al. 2019), and is well placed in populist and authoritarian discourses. Politicians are the key culprits using the term as a weapon. 
Wardle (cited in Giuliani-Hoffman 2017) exemplified mal-information: "That might be my mom sharing a shock photo from Hurricane Irma" without checking it properly, and it could be an old image from another event. Examples of mal-information are Hillary Clinton's leaked emails in 2016 or the spread of hoaxes around the false existence of a gaykit, allegedly distributed in Brazilian fundamental schools by the Workers Party candidate to the 2018 presidential elections (G1 2018). Mal-information also includes some hate discourse.

Egelhofer and Lecheler (2019) propose dealing with false news under a narrower umbrella, just to better understand it. So, we would have (1) the fake news genre, i.e., "the deliberate creation of pseudo-journalistic disinformation", and (2) the fake news label, i.e., the instrumentation of the term (and its inherent negative connotation) to delegitimize news media.

Our attention is focused on the world of journalists: how they feel, think, and evaluate the false material that is released daily under the label of "news", confusing the population and putting at risk the credibility of those who are seen as "professional news makers". In our research we deal mainly with fake news as a genre, but a splattering from the second one (fake news label) will certainly be felt through the analysis, since this is not an isolated item. We agree with those authors who state that a message shall be studied as fake news when:

1. It is low in facticity-it contains false information, false connections, false context, manipulated content, or misleading content (Wardle 2017), either fully or partly (Tandoc et al. 2017);

2. It is presented in a journalistic format-it is an imitation of news. Fake news "mimics news media content in form" (Lazer et al. 2018), and is presented in a journalistic format following certain standards: similar components-the structure with a headline, text, and image — or, if it is a video or audio, pseudo-journalistic aspects may mislead recipients;

3. It is created with the intention of deceiving - the main motivations are political, ideological, or financial, but fake news can be created in a humorous mood, to entertain, or to provoke (Wardle 2017) mental results, their interpretation, and the experimental conclusions that can be drawn.

\section{Materials and Methods}

Where previous studies focused on the explosion or scandal brought on by fake news, this study focused on what all this discussion causes for the so-called journalistic class and what the opinion is of the ones who produce "real news".

We provide an analysis of journalists' perspectives on fake news based on qualitative data from Portugal and Brazil. The research covered a wider range of topics as part of our project "The Discursive Explosion of False Information and the World of Journalists" and included specific questions on issues about fake news and trust, addressed to professionals in different kinds of media. A total of 210 journalists answered the questionnaire from many different regions of Brazil² .

To examine the replies, we used a mix of quantitative and qualitative techniques in a balance that allowed for a critical understanding of the messages and their meanings, in addition to facilitating the investigation of phenomena laden with symbolism (Bardin 2011), as is the case with fake news.

In Portugal (October 2019-March 2020), the questionnaire underwent some additions as well as some deletions, resulting in an 11-question form. However, the efforts to adapt the research to the Portuguese reality was unsuccessful: The national agency for communications (ERC - Entidade Reguladora para a Comunicação Social) could not send out the questionnaires and our attempt to contact the media and send the form to their mailing list had no effect ${ }^{3}$. We chose to interview journalists directly and carried out 10 interviews, half with Portuguese journalists and the other half with Brazilian journalists (Table 1). 
Table 1. Research sample in Portugal and Brazil.

\begin{tabular}{|c|c|c|c|c|}
\hline Interviewee & Vehicle & Mode & Gender & Country \\
\hline Interview 1 & $\begin{array}{c}J N \\
\text { newspaper }\end{array}$ & In-personal & M & Portugal \\
\hline Interview 2 & $\begin{array}{l}\text { TSF } \\
\text { radio }\end{array}$ & E-mail & M & Portugal \\
\hline Interview 3 & $\begin{array}{l}\text { Jornal do Fundão } \\
\text { newspaper }\end{array}$ & In-personal & M & Portugal \\
\hline Interview 4 & $\begin{array}{l}\text { Rádio Cova da } \\
\text { Beira radio }\end{array}$ & In-personal & $\mathrm{F}$ & Portugal \\
\hline Interview 5 & $\begin{array}{l}\text { SIC } \\
\text { TV }\end{array}$ & E-mail & $\mathrm{F}$ & Portugal \\
\hline Interview 6 & $\begin{array}{l}\text { Globonews } \\
\text { TV }\end{array}$ & WhatsApp & M & Brazil \\
\hline Interview 7 & $\begin{array}{c}\text { Veja } \\
\text { magazine }\end{array}$ & E-mail & F & Brazil \\
\hline Interview 8 & $\begin{array}{l}\mathrm{CBN} \\
\text { radio }\end{array}$ & WhatsApp & $\mathrm{F}$ & Brazil \\
\hline Interview 9 & $\begin{array}{c}\text { O Globo } \\
\text { newspaper }\end{array}$ & E-mail & M & Brazil \\
\hline Interview 10 & $\begin{array}{c}\text { Valor Econômico } \\
\text { newspaper }\end{array}$ & E-mail & M & Brazil \\
\hline
\end{tabular}

Source: authors, 2020. For ethical principles, the names and functions are hidden.

Our concern, then, was to balance the sample (Table 1). We did three face-to-face interviews, two by closed-messaging apps, and five via e-mail. In late March 2020, when COVID-19 was already a threat, turning people to privacy safeguards, the questionnaire was reduced to eight questions, to be addressed by electronic mail or quick messaging.

\section{Results and Discussion}

First, we verified the word frequency. All the responses summed up a total of 4861 words. Obviously, the most cited expression was "fake news" (44 times), attesting that the term was well recognized by the journalists; "false news" (9) was also used; and two others also appeared frequently-"literacy" (2) and "education" (5). Second, we grouped the questions. A total of $80 \%$ of the respondents gave answers to all questions. Here we present a selection ${ }^{4}$ from all the answers received; however, the quotations are the original ones. Although the interviews were in Portuguese, the translation (by the authors) strives to maintain the thoughts and ideas of each interviewee.

Next, we will take a look at the problem question by question, highlighting the main answers. Each respondent is identified only by an I (Interviewee), followed by an order number, for example, I1. To preserve their identity, names have been omitted.

\section{Q1: Did you receive fake news?}

All respondents answered "yes" to Q1, leading us to believe that fake news is a reality in peoples' connected life. However, some diverged on the definition of fake news or simply did not have an assertive response for Q2, as we will see.

\section{Q2: What, in your opinion, is fake news?}

Interviewee 2 (I2) confessed, "I have some difficulty with the designation of false news. By definition, news is true. What we usually call false news, I prefer to call a lie, a falsehood. An attempt to deceive people". To I5, fake news is "those in which the facts do not correspond to the truth of the events". I6 said, "That name [fake news] comes from the old practice Brazilians have of importing things from outside. Fake news is a beautiful 
term. It's false news. If we put this as virtual gossip, people would be embarrassed to share it". I6 even rehearsed a classification of fake news into five groups:

- Those that produce and have an interest in it;

- A journalist who publishes news not confirmed due to the desire to publish, creating anxiety and confusion. This becomes false news, because it creates expectation;

- Manufactured news, made by robots with political interest;

- Created as a game, a joke;

- Journalists who induce readers to click on news when in fact the subject is not that. Recently a portal published that a university student was missing. However, at the bottom of the text was the information that the student wrote a letter to the family and decided to leave the house. This is great fake news that induces the reader to read a news piece that is not true (I6).

The negative character of false information and the format chosen to present it-e.g., with a news structure-is remarked on below:

"[Fake news] is news built, shaped to denigrate, defame, completely alter a fact that has happened. It is not even false news by mistake that journalists eventually commit. News taken from the imagination of a person, a group, distorting reality, with the aim of spreading a theory that is usually conspiratorial and that makes no sense" (I7).

"There are different levels of fake news. Some are easy to spot right away, as they bring awkward approaches. Others are well 'disguised' as news, but usually can't resist a quick Google search. There are still distorted narratives created based on facts, which have been very common lately. You go to YouTube, for example, and watch videos that reproduce excerpts from a press conference of political agents and distorted comments on the topic, whether to idolize or criticize those involved. The same occurs on blogs or social networks" (I10).

\section{Q3: How do you identify fake news?}

I4 responded with an idiom: "When alms are too much, even the saint is suspicious ${ }^{5}$. I always put two feet behind". She argued that the experience shows the way. "We journalists know how to identify them", declared I3. For I2, "The way I identify them depends a lot on the way they reach me. In social networks, 'news' appears several times, whose origin is doubtful: sites that I have never heard of or that I have identified as typical fake news vehicles. But I have also received fake news from media registered at the $\mathrm{ERC}^{6 \prime \prime}$.

The science of verification is one of the premises of good journalism and was stressed by most of the respondents. "Sometimes it is evident, because it contradicts a known fact. Sometimes it hides a statement from a public figure (...). In this case, it is worth checking on credible vehicles, official websites or directly with individuals" (I9). Finally, I1 stated, "'Let him who is without sin, cast the first stone', but the important thing is to know how to check the information. The journalists who work in digital [media] have to validate the data in all possible ways and shapes to avoid spreading false news".

When conceptualizing the problem, journalists from Portugal and Brazil agreed and shared the same concerns over the spread of fake news; however, they had different feelings about its consequences in the society where they live and work. It seemed, for example, that Brazilian journalists are much more exposed to false news and thus talked quite frankly about it.

\section{Q4: Can you give me an example of two pieces of fake news that marked you?}

Portuguese journalists pointed out more general facts regarding the theme: "Demands from the blood institute (...) are not true. The institute has its own methods of asking for donations and a calendar. And there are those that ask for money from institutions", said I4, who has a radio program and never passes on that kind of information, even though she is harassed with false content. I2, a radio journalist from a well-known Portuguese media organization, gave two examples of doubtful information:

"A newspaper recently reported that the Government was going to release prisoners convicted of rape and violent crimes, which was not accurate to proclaim. 
Also, recently, several news organizations stated that the new Lisbon airport in Montijo was no longer going to advance because of the pandemic, which was similarly false" (I2).

The COVID-19 crisis arises naturally as an issue of the moment. I1 reminded us that the "conspiration theory" regarding the virus's origins-that it was developed in a Chinese laboratory - appeared quickly, but he assured us that the (Portuguese) newspaper where he works only publishes information "with 500\% guarantee". At the beginning, much conflicting information circulated in the journalistic medium. I5 asserted that, when Portugal was still debating whether or not [to proclaim] a State of Emergency, she learned about the decree during a phone call with a colleague:

"She told me that the State of Emergency had been enacted. I asked her about the certainty that she showed on the subject, because I had the information that the decision would only be known later. She told me that she had received, at that very moment, the alleged 'decree' through her husband, also a journalist. I researched and found that the President was still listening to the parties. The truth is that the lie gained a 'truth value' when it was broadcast on a network of people who considered themselves credible sources. The lack of a sieve would have paved the way for media coverage. But when confronting several sources, it was possible to verify that the document was forged" (I5).

In Brazil, two important cases were mentioned by I6 as examples of fake news:

“Our president [Bolsonaro] posted a user's video on his social network, saying that Ceasa [a large market for horticultural products] was short of supplies. It was not true. He replicated this video without checking the source (...). This had a practical effect: people became desperate and went after food. Press managed to clarify all that. Last week, it came a buzz that Mandetta [Luiz Henrique, the Ministry of Health] would be fired. As delicate as the situation is, I think that journalism should only publish information when it is certain" (I6).

The Brazilian group cited other emphatic illustrations of fake news, many of them related to COVID-19. One message affirmed that China produced COVID-19 to break down the economy of other countries and profit from it (I10); before the pandemic effects got to Brazil, a note received by I10 stated that the virus would not survive in the country "because it would be burned by the sun". Another one, more recently, gave the improbable news that "the coffins of supposed coronavirus victims are empty when buried, because the pandemic 'is not all that', instead it should be part of 'a global collective hysteria'" (I7). Another piece of false news was that drinking hot water would kill the virus and that "drivers without masks would be fined based on the Brazilian Traffic Code. The message even brought details of the fine" (I8). I9 remembered two cases from 2018 elections: "Venezuelans defrauding Brazilian electronic ballot boxes" and a video (that had a lot of repercussions) stating that "the stab against the then candidate Bolsonaro was false". ${ }^{7}$

Q5: Do you foresee that, in the next elections [in Portugal and Brazil], there could be a spill of false news?

"Elections are unpredictable and websites are evil and cheap tools", reflected I1. Portuguese journalists stated that false websites, dedicated to disinformation, appeared and disappeared in a short period of time. Because of that, I3 thought that "social media is a serious problem". He gave a warning, as he did not see anyone worried about that: "I think Portugal has to be alert. There are signs that the topic is starting to become important. They are undermining information and whoever does serious journalism. (...) We will lose readers to manipulation, extremism".

In Brazil, all journalists from our sample answered Q5 positively.

"In all elections-both in the last and in future-there will be a fake news spill, because the so-called traditional journalism is being attacked more by the alter- 
native media, by the 'WhatsApp Aunts', people who are informed by the social media, who gained projection and a voice that they didn't have before. Look, people who do not know what they are saying now speak and get reverberation by these means. I see nothing that electoral justice can do (...). One way out of this flow is to strengthen traditional vehicles, not because they are traditional, but because the profession of journalism has filters that minimize the chance of absurdity that is said in social media networks" (I7).

The last three questions referred directly to the participation (or not) of journalism in the ecosystem of production and distribution of news.

\section{Q6: Do you think journalism has a responsibility regarding fake news? Why?}

Our research corpus was divided over the media's responsibility for fake news.

"It's painful to say this but I think it does [have responsibility on fake news distribution]. As in all professions, there are good and bad professionals. This does not characterize the profession per se. But above all, I think that there are media outlets that deliberately deceive people and are not punished for that. (...) And I distinguish between what is a mistake of an individual journalist-who is human-from what is a deliberate falsehood, without guilt or error being assumed later. Unfortunately, neither the ERC nor the [Portuguese] License Commission $^{8}$ fulfill their role" (I2).

I2 thought that the reason why a media outlet or a journalist deliberately "deceives the audience" relates "mainly with commercial reasons" in order to sell more newspapers or to have more engagement. "But that is exactly what regulatory institutions are for", he said. I4 stated, "Often, to put bread on the table, the journalist has to answer to an editor and do what he is told. I leave this kind of reflection here". Then, I3 mentioned, "We're entering a dangerous terrain. Anyone can set up a 'specialized' website and spread things that go viral. I've seen many denials on social media, often from politicians, because of rumors that go viral".

As for I1, the explosive dissemination of disinformation involves a regulatory problem that should be addressed by European regulation: "There is a market dominated and undermined by technology giants, Facebook and Google. (...) No matter how much they state that they are fighting it and that there is an effort to do fact checking and start sorting pages, the problem remains evident", because, he argued, these companies "dominate 100 or $80 \%$ of the content, there is very little left for others". I5 reflected that one of the professions' elements, the commitment to the truth: "Let me highlight what may be the usable balance of a scheme that is rotten. (...) Fake news hides wonderful 'true news'. In journalism I learned that it is necessary to look behind the mirror". She added, "Journalists have in their hands the ability to 'disassemble' and expose the interests beyond fake news; if and when they do this it will be a true 'turning of the spell against the sorcerer" (I5).

Notwithstanding the negative landscape, some of our interviewees thought that journalism may be part of the lack of credibility thrown on the shoulders of journalists, and others did not. "I don't think directly", argued I8, stating that she believes that "journalism should be more 'effective', tougher in combating fake news". On the other side, I7 called attention to the fact that much of the disturbance "is more the reverberation that social media allows to people ( ... ) less responsibility to journalism and more to discourses that only serve the interests of the propagator. Those are deliberately made to mix reality with fiction and are, from birth, thought to achieve reputations or distort information" (I8).

\section{Q7: To what extent does false news endanger journalists' credibility?}

Responses to Q7 were divided among those who shared a strong feeling that the profession and the career have a guaranteed function in democratic societies (A), and others who believed that journalism is being constantly challenged nowadays (B). 
(A) "Credibility is the greatest asset that journalism can have. If we throw it away, the profession will no longer be respected, people will think they do not need us, and the economic effects will be-as they are-a disaster" (I2).

(A) "Journalism must continue to fulfill its mission and, therefore, I do not think it is threatened. We must take advantage of the fact that there is information circulating that is not certified. So, we assert our notoriety, our value. What we can add is credibility, trust, truth, things that fake news do not bring. There is no machine that can investigate, you can write a news report from the weather, but only journalism has the capacity to tell stories, certify them, and its path will be the same, the search for the truth" (I1).

(B) "In a parallel world, there are very efficient actors who attack journalists as diffusers of information and depreciate media organizations, doubting its credibility. Before the resignation of Minister Sergio Moro ${ }^{9}$, the media was accused of wanting to destabilize the Brazilian government, planting an intrigue between the President and his most popular minister, (...) to force an impeachment. But reality imposed itself over the 'WhatsApp Aunts' and their gossips" (I7).

(B) "We have been following a lot of false content that is, in fact, true. In addition, many of these fake news are accompanied by details and criticism to the press or to specific journalists. Perhaps this generates social commotion and more pressure on the media in general. About the journalist: I don't see that it affects credibility, but until these fake news are vehemently denied with data by the press itself, and his/her image (...) is reestablished, we cannot negate it reaches, in fact, each of us. (...) At least this is not a phenomenon restricted to our profession. 'The death of expertise', to remain in the title of Tom Nichols' book, occurs in all areas of knowledge as we move towards this increasingly horizontal and unfiltered world" (I9).

\section{Q8: Will there be journalism after fake news?}

In this question we deal with the symbolic charge that has been attributed to journalism. There are two important aspects:

The first one is that, in the minds of audience sectors, journalism produces false news. People seem to think that countless websites dedicated to disinformation are fed by professionals from newsrooms trained in journalism schools or media labs, and that fake videos are allegedly shot by journalists linked to TV broadcasters.

The second aspect is that journalism, as the fourth power, is an ally of the hegemonic forces and not a profession sworn to a public service and duty, to inform the population with impartiality and objectivity.

Those two aspects, together with concerns about the future of journalism, appeared in the following answers:

"If people want to [that journalism continues to exist], yes. They must realize that serious journalism, which has a purpose, is an expensive thing, which needs funding. There ought to be a policy for media literacy, and the way out is still education. Everyone should get involved: the government, the schools, the media organizations. There is no other way: the survival must come through education" (I3).

"This is, in fact, the only certainty I have. Fake news can eventually create a need for people to trust someone again. And this pandemic is a proof of that: at such an important moment, people started looking for journalism once more. The biggest problem is the economic survival of journalism and, in that field, it will be up to the governments to have the courage to make decisions. Journalism cannot be confused with a Facebook post. Nor with a text on a blog or with articles published on ad hoc sites. States must regulate once and for all the major digital platforms and compel them to pay for the product they use and resell. It 
is necessary that regulation be more demanding with the criteria for granting licenses to the media and professional journalist license. And it is necessary, by the way, that the media companies reinvent themselves and find new business models" (I2).

Indeed, that was one question that had unanimity from our respondents: All of them thought that no, false information will not prevail over journalism. "Fake news is a bad phase, it will pass", I4 assured, and I9, admitting his optimism, declared, "There will always be journalism. We need to know how to identify the enemies of the profession and of good journalism inside and outside it, in order to expose its flaws and bad faith. This is part of the strategy" (I9). He pointed out that, to contribute to the "reinvention" of the activity, we must invest in media education, "which may not have been so necessary before, but which is now crucial". ( . . ) Doing this we preserve sectors of society, which I hope will continue to be expressive (...), who are interested in a critical press, (...) without working for political groups. I believe that we can maintain vibrant and relevant journalism for the population that wants it" (I9).

I6 remembered that, in Brazil, since 2013, the relationship between the press and the public has become worn out. With demonstrations in the streets against the government, people felt also unhappy with the performance of the press. Now, he stated that he finds "it is the best moment for the press. I believe that people are coming back to believe and trust the press, thanks to our work". For him, the press's daily job is "almost like that of a football judge. Hard to please everyone". However, "the main objective is not to please but to inform what is happening".

Contradicting the belief that false news could be a menace, I5 affirmed that "fake news is the latest proof of the importance of journalism": "In an era when information circulates faster than the wind, there is the ignorant illusion that any citizen, with a cell phone, can be a journalist. Nothing could be more wrong". According to I5, "if fake news defies journalism, we must respond with professionalism". It is not, whatsoever, "the poison of journalism", for other factors are destabilizing the practice.

Journalism is stamped by investigation. Unfortunately, in newsrooms with increasingly younger professionals, who are underpaid and pressured to work quickly, the temptation to take the easy route leads to an ever-greater reduction in the power to investigate. "What can kill us is everything that robs us of independence: the lack of time, the lack of resources, the lack of training, the low wages that compel young journalists to look for activities other than journalism", stated I5.

Another point of unanimity was that "journalism needs to be strengthened" (I6). There was also a big concern about information during the pandemic. "The press has a fundamental determining role in informing about the risks", said I6, remarking that "it is important to bring the population closer to the press (...), to recover credibility", and to be careful about not passing on false information. The opinion of I7 was that "fake news are threatening, but they do not jeopardize the future of journalism, because every journalist is committed to the reality of the facts, unlike the authors of false information". Even so, she thought that the newspapers "are reinventing themselves because of other voices and the rise of social media". Despite the "important financial crisis", she argued, "there will be journalism exactly as a source of credible, checked information". I10 had a similar opinion, stating, "There will always be room for professional journalism. But it changes constantly. We will need to rethink practices to increasingly turn journalism into a reference for credibility, responsibility, ethics, empathy".

\section{Conclusions}

Journalistic practice has gone through different stages in its trajectory. Mutations affect the production of news, the profile of journalists and the relationship of these professionals with audiences (Pereira and Adghirni 2011; Jorge 2013). For Brin et al. (2004), the transformations are part of the natural process of evolution, which goes through moments of 
stability and profound changes, influenced by cultural, social, legal, political, technical, and economic aspects.

Nowadays, beyond the desired space for free expression brought on by the participation of the public in manufacturing the news, and the free expression of opinions, there are also large-scaled and orchestrated manipulations of information, present mainly in electoral periods (Pena 2019). Although our sample is small-due to the circumstances of the pandemic situation - we can infer that some statements of the journalists surveyed can be projected to the universe of professionals who practice journalism in the Western world.

The focus of the paper was on the transitions of journalism, the phenomenon of polluted (even toxic) information, and how the spread of fake news can affect journalists and their role in the future. The purpose of this work was to find what the recent appearance of fake news represents for journalists. We chose to research fake news as a genre (Egelhofer and Lecheler 2019) because some sectors of public opinion consider that it is the media companies that produce fake news, wreaking havoc on the professional image and reputation of journalism. In our interviews, we identified a sensible point of concern for journalists, and so we asked questions about self-image, credibility, and the future of journalism.

Social media are spaces fed with user-generated content that enable interpersonal communication. This new environment, though, has empowered people whose comments carry the same weight as expert opinions (Nichols 2017). As our corpus pointed out, conspiracy theories, hoaxes, and misinformation rush to get to readers' accounts with no vetting, as if they were credible sources. Those who recklessly spread all kinds of news are ironically called by one of the journalists (I7) the "WhatsApp Aunts". Remarking that only journalism tells the stories, only journalism investigates the cases and offers credibility as an asset to the public, the group commented on and concisely reinforced the ideological and technical values of the profession and refused "automedia" (Lévy 2002) initiatives.

As we could see, the journalists of our sample were very proud of their expertise and really thought the fake news wave is not "the poison of journalism": On the contrary, it represents a chance for the activity to recover and to reinvent its practices, to seduce the audience again. They saw themselves, as journalists, as being committed to the reality of the facts, unlike the authors of false information. Some of the journalists mentioned ethical issues-such as journalists' responsibility for the veracity of the information they disclose and their commitment to checking data-but they did not delve into this topic. Anyway, that was not the focus of this research.

More so in Portugal than in Brazil, it seemed that the sector is aware of a scenery of deregulation and its consequences in the short and long term. This in itself is a contradiction, since Brazilians are bombarded daily by such an incredible flood of fake news involving the president and ministries. Nevertheless, the latter diminish the necessity of laws more than the Portuguese journalists, who assist in the action of at least 40 websites that are responsible for the spread of disinformation, mal-information and misinformation disseminated from programmed computers and bots (Pena 2019). These Portuguese perceptions are in harmony with the Eurobarometer, which informs that $73 \%$ of Europeans share great concerns over the effects of disinformation (Pena 2019) ${ }^{10}$.

Despite the differences, our groups reacted similarly to the question of audience awareness. They agreed that the best way to fight against fake news is information, starting by training in schools. It is necessary for societies to invest in media literacy to teach how to read, interpret, and distinguish rigorous and valid information.

As for the term "fake news" itself, its use as a label, and the implicit hostility it carries, our study suggests that it has a negative impact on the press and on the way that society looks at the media. The discursive exploration of the phrase also contributes to delegitimizing organizations and to polarizing political positions. Because of that, some journalists in the sample urged their colleagues to defend the profession against falsehood, mainly in times of pandemic, when there is a flood of disinformation in the air.

Finally, most of the journalists in the sample thought they must be more cautious to check sources for veracity and for political motivations. When we asked to what 
extent false news endangers journalists' credibility, the journalists seemed to think that the profession has a guaranteed function in democratic societies, although others believed that journalism is being challenged. Actually, there is a need to reinforce the importance of professional journalism, done with ethical premises and adhering to truth, to verification, and to transparency in times of digitalization, taking care with social media and using the available tools to approach the public's needs. The recipe to do this is summed up in three points: (1) regulation, (2) education, and (3) fact checking.

The findings of this study have to be understood in the context of some limitations. We know that a content analysis can only analyze manifest content-in this case, the interviews or texts written by the sample's journalists. We could not record the motivations or the real intentions behind what was said. What we present here is a panel of feelings, perceptions, and symptoms of the changes that are currently taking place in journalism in two Portuguese-speaking countries, which are similar in their culture, habits, and traditions. However, as fake news seems to be an "evil of the century", we can infer that this feeling of discomfort expressed by journalism professionals could be shared by colleagues in other parts of the world, as everyone deals with news on a daily basis and is subjected to real-time manipulation brought on by digital media and countless other means.

Our 10 interviews in Portugal and Brazil, and the complexity of the questionnaire responded to by active, qualified journalists in the two countries, illustrate methodological qualitative tactics for exploring structured conversations between researchers and professionals as relational opportunities to discuss themes that pulse and disturb society. The theme also works for comparative studies in the future, collecting impressions of journalists in different countries or comparing them in a timeline, in order to discover how they evolve, how they resemble each other, and how they differ. Further research should also address a broader sample and in-depth interviews, as well as audience investigations. In addition, if we understand our research as an experiment, it suggests that the malaise provoked by fake news can be taken as an empirical occasion to academically explore the scenery that brought about these unsettling effects.

Author Contributions: Conceptualization, J.C. and T.d.M.J.; methodology, T.d.M.J.; software, T.d.M.J.; validation, T.d.M.J.; formal analysis, J.C. and T.d.M.J.; investigation, J.C. and T.d.M.J.; resources, J.C. and T.d.M.J.; data curation, J.C. and T.d.M.J.; writing—original draft preparation, T.d.M.J.; writingreview and editing, J.C. and T.d.M.J.; visualization, J.C. and T.d.M.J.; supervision: J.C. All authors have read and agreed to the published version of the manuscript.

Funding: This research received no external funding.

Institutional Review Board Statement: Ethical review and approval were waived for this study because the participants are not identified.

Conflicts of Interest: The authors declare no conflict of interest.

\section{Notes}

A paper with this theme was presented at the 2nd Multidisciplinary International Symposium on Disinformation in Open Online Media (Misdoom). 26-27 October 2020 (online), Leiden University, The Netherlands.

2 The first study was carried out in Brasilia, Brazil, between September and October 2018. In that survey (September 2018), we included journalism teachers. For the journalists themselves we used the mailing list from the Brazilian Federation of Journalists. We only received two questionnaires, which were insufficient for our analysis.

The selection was based on the most significant answers or those that reached the central point of the question asked.

"Quando a esmola é muita, todo santo desconfia".

Entidade Reguladora para a Comunicação Social (Portuguese Regulatory Authority for the Media Social) is an independent administrative agency.

On 6 September 2018, Jair Bolsonaro was stabbed during the 2018 presidential campaign.

Comissão da Carteira Profissional de Jornalista, an independent organization governed by public law that oversees the practice of the journalistic profession in Portugal.

9 Brazilian Minister of Justice Sérgio Moro resigned after a conflict with President Jair Bolsonaro in late April 2020. 
In fact, currently there are several media literacy projects in Portugal, some of which are led by newspapers. A good example is the newspaper Público, which publishes the P3 supplement and distributes newspapers at universities for free. Another interesting initiative was led by the Union of Journalists, which, together with the Ministry of Education, organized teacher training activities related to media education.

\section{References}

Allcott, Hunt, and Matthew Gentzkow. 2017. Social media and fake news in the 2016 election. Journal of Economic Perspectives 31: 211-36. [CrossRef]

Bardin, Laurence. 2011. Análise de Conteúdo. São Paulo: Edições 70, p. 229.

Brin, Colette, Jean Charron, and Jean de Bonville. 2004. Nature et transformation du journalisme: Théorie et recherches empiriques. Québec: Les Presses de l'Université Laval.

Canavilhas, João. 2010. O novo ecossistema mediático. Covilhã: Biblioteca Online de Ciências da Comunicação.

Carlson, Matt. 2017. Journalistic authority: Legitimating news in the digital era. New York: Columbia University Press.

Egelhofer, Jana Laura, and Sophie Lecheler. 2019. Fake news as a two-dimensional phenomenon: A framework and research agenda. Annals of the International Communication Association 43: 97-116. [CrossRef]

Eco, Umberto. 1984. Viagem na irrealidade cotidiana. Rio de Janeiro: Nova Fronteira, p. 234.

Foucault, Michel. 1988. História da Sexualidade. Rio de Janeiro: Graal, p. 9.

G1. 2018. É \#Fake que Haddad criou kit gay para crianças de seis anos. Available online: https://g1.globo.com/fato-ou-fake/noticia/ 2018/10/16/e-fake-que-haddad-criou-kit-gay-para-criancas-de-seis-anos.ghtml (accessed on 7 May 2020).

Gelfert, Axel. 2018. Fake News: A Definition. Informal Logic 38: 84-117. [CrossRef]

Giuliani-Hoffman, Francesca. 2017. 'F** News' Should Be Replaced by These Words', Claire Wardle Says. CNN. Available online: https://money.cnn.com/2017/11/03/media/claire-wardle-fake-news-reliable-sources-podcast/index.html (accessed on 7 May 2020).

Gray, Jonathan, Liliana Bounegru, and Tommaso Venturini. 2017. 'Fake news' as infrastructural uncanny. New Media and Society 22: 317-41. [CrossRef]

Guo, Lei, and Chris Vargo. 2018. "Fake News" and Emerging Online Media Ecosystem: An Integrated Intermedia Agenda-Setting Analysis of the 2016 US Presidential Elections. Communication Research 47: 178-200. [CrossRef]

Jorge, Thaïs de Mendonça. 2013. Mutação no jornalismo. Como a notícia chega à internet. Brasília: Editora Universidade de Brasília.

Kovach, Bill, and Tom Rosenstiel. 2004. Os elementos do jornalismo. São Paulo: Geração.

Lazer, David M., Matthew A. Baum, Yochai Benkler, Adam J. Berinsky, Kelly M. Greenhill, Filippo Menczer, Miriam J. Metzger, Brendan Nyhan, Gordon Pennycook, David Rotschild, and et al. 2018. The science of fake news. Addressing fake news requires a multidisciplinary effort. Science 359: 1094-96. [CrossRef] [PubMed]

Lévy, Pierre. 2002. Cyberdémocratie. Paris: Éditions Odile Jacob.

Nielsen, Rasmus K., and Lucas Graves. 2017. "News you don't believe": Audience Perspectives on Fake News. Available online: https: // reutersinstitute.politics.ox.ac.uk/sites/default/files/201710/Nielsen\%26Graves_factsheet_1710v3_FINAL_download.pdf (accessed on 3 May 2020).

Nichols, Tom. 2017. The Death of Expertise: The Campaign Against Established Knowledge and Why it Matters. Oxford: Oxford University Press.

Pena, Para. 2019. Fábrica de mentiras. Viagem ao mundo das fake news, 1st ed. Lisboa: Penquim Random/Unipessoal.

Pereira, Fábio Henrique, and Zélia Leal Adghirni. 2011. O jornalismo em tempo de mudanças estruturais. Intexto 1: 38-57.

Quandt, Thorsten, Lena Frischlich, Svenja Boberg, and Tim Schatto-Eckrodt. 2019. Fake News. Available online: https://www. researchgate.net/publication/332749986_Fake_News (accessed on 6 May 2020).

Schaub, Michael. 2017. Trump's Claim to Have Come up with the Term 'Fake News' Is Fake News, Merriam-Webster Dictionary Says. Available online: www.latimes.com/books/jacketcopy/la-et-jc-fake-news-20171009-story.html (accessed on 4 May 2020).

Silva, Juremir Marchado. 2019. Fake news, a novidade das velhas falsificações. In As fake news e a nova ordem (des) informativa na era da pós-verdade. Edited by Joao Figueira and Silvio Santos. Coimbra: Coimbra University Press, pp. 33-45.

Silverstone, Roger. 2014. Por que estudar a mídia? 4th ed. São Paulo: Loyola.

Steinmetz, Katy. 2017. The Dictionary Is Adding An Entry for Fake News. Available online: https://time.com/4959488/donald-trumpfake-news-meaning/ (accessed on 7 May 2020).

Tandoc, Edson, Jr., Wei Lim Zhang, and Richard Ling. 2017. Defining "fake news". Digital Journalism: A Typology of Scholarly Definition 6: 137-53. [CrossRef]

The Conversation. 2019. The Real News of 'fake news': Policians Use It to Discredit Media and Journalists Need to Fight Back. Available online: https:/ / theconversation.com/the-real-news-on-fake-news-politicians-use-it-to-discredit-media-and-journalists-needto-fight-back-123907 (accessed on 7 May 2020).

The Merriam-Webster Dictionary. 2017. The Real Story of ‘Fake News'. Available online: https://www.merriam-webster.com/wordsat-play/the-real-story-of-fake-news (accessed on 2 May 2020).

Wardle, Claire. 2017. Fake News. It's Complicated. Available online: https://firstdraftnews.org/latest/fake-news-complicated/ (accessed on 7 May 2020). 
Wardle, Claire, and Hossein Derakshan. 2017. Council of Europe. Available online: https:/ /rm.coe.int/information-disorder-towardan-interdisciplinary-framework-for-researc/168076277c (accessed on 6 May 2020).

Wolton, Dominique. 2005. Il faut sauver la communication. Paris: Flammarion.

Wolton, Dominique. 2010. Informar não é comunicar. Porto Alegre: Sulina. 